\title{
Anthropogenic impacts on Tiger frog Hoplobatrachus tigerinus, at Biratnagar and its surroundings, Nepal
}

\author{
Minu Kumari Sah and Bharat Raj Subba \\ Department of Zoology, Post Graduate Campus, T.U., Biratnager, Nepal \\ E-mail: cute_doll1567@yahoo.com
}

Key words: Anthropogenic impact, Biratnagar, Tiger frog, dissection of frog, urbanization

Tiger frog (Hoplobatrachus tigerinus) is a freshwater amphibia found in freshwater ponds and ditches. It hides under the stone, log, grasses and in damp places, and when its skin becomes dry it jumps into the water. It has squat body, smooth skin, and strong hind legs with webbed feet. They reproduce by laying eggs in water. Frog is a carnivorous animal. It feeds on earthworms, insects, spiders, etc. However, the tadpoles are herbivores feeding on aquatic plants. The frog is a poikilothermal animal therefore it cannot bear very cold or very hot temperature. The frog needs hibernation and aestivation to tide over the unfavorable conditions. They remain active in spring and rainy seasons. It is an important component of ecosystem. It controls the agricultural pests and it is used for medicinal purposes as well. Some people use it as meat.

Anthropogenic threats are varied and numerous. Urbanization, industrialization, lack of public awareness, maximum uses of frog as dissecting material in educational institutions, uses of pesticides, catching for consumption and climate change are some of the prevailing anthropogenic impacts on Tiger frog. With increase in human population the aforesaid threats are also hiking up. Taking the declining population of Tiger frog Hoplobatrachus tigerinus into consideration, study of anthropogenic impacts on the Tiger frog at Biratnagar and its surroundings was attempted. Biratnager is an expanding industrial city where anthropogenic impacts on Tiger frog are increasing in intensity day to day. A perusal of literature reveals that there is a lack of literature related to anthropogenic impact on Tiger frog.

To study anthropogenic impacts on Tiger frog Hoplobatrachus tigerinus, questionnaires were used with a view to know the way the institutions procure frogs, the number of frogs used each year and awareness of public about the conservation of the declining population. The questionnaires were distributed to ten institutes namely COBASS College, Arniko H.S.S., Sikshadeep H.S.S., Orchid pubic H.S.S., Greenland International H.S.S., Birat Science Campus, Lord Buddha H.S.S., Star H.S.S., National Academy and Holyland H.S.S for actual data and authentic answers. Interviews also were taken with zoology teachers, lab boys, frog collectors and local people .Direct field observations were done randomly.

The results of the studies show that the declination of the tiger frog Hoplobatrachus tigerinus is because of anthropogenic impact and climate change. Anthropogenic impact comprises habitat loss, urbanization, and excessive use of insecticide, maximum use of frog in zoology practical and lack of awareness about its importance. In the past human population was small so frog habitats were safe but within two or three decades human population explosion has taken place. In Biratnagar immigration is increasing day by day. Loss of habitats is the biggest trend found in Biratnagar. Most of the land has been 
encroached for different purposes such as agriculture, human settlement; establishing industries etc. No place is untouched either on both sides of the highway or sub-roads. Even banks of rivers like Singhiya have almost been occupied by houses and mills. This trend resulted in decline in frog population. The use of pesticides in agriculture, garden, orchard has been common in Biratnagar. This sort of practice is not only detrimental to insects but also to insectivorous animals. Unmanaged uses of frogs in zoology practical also have become one of the remarkable anthropogenic impacts (Tab. 1).

Table 1. Frogs used in 2010, 2011 and 2012 in educational institutions at Biratnagar.

\begin{tabular}{|c|c|c|c|c|c|c|c|c|}
\hline \multirow{2}{*}{ SN } & \multirow{2}{*}{ Name of the campus } & \multicolumn{3}{|c|}{$\begin{array}{c}\text { Class XI students in } \\
\text { the year of }\end{array}$} & \multirow{2}{*}{$\begin{array}{l}\text { No. of frogs } \\
\text { dissected by a } \\
\text { student }\end{array}$} & \multicolumn{3}{|c|}{$\begin{array}{c}\text { Total no. of frogs } \\
\text { dissected in }\end{array}$} \\
\hline & & 2010 & 2011 & 2012 & & 2010 & 2011 & 2012 \\
\hline 1 & COBASS College & - & 140 & 120 & 2 & - & 280 & 240 \\
\hline 2 & Arniko H.S.S. & 300 & 310 & 310 & 2 & 600 & 620 & 620 \\
\hline 3 & Sikshadeep H.S.S. & 250 & 330 & 500 & 3 & 750 & 990 & 1500 \\
\hline 4 & Orchid Public H.S.S. & 150 & 135 & 144 & 6 & 900 & 810 & 864 \\
\hline 5 & Greenland Intn. H.S.S. & - & 120 & 100 & 6 & - & 720 & 600 \\
\hline 6 & Birat Campus & 200 & 60 & 100 & 5 & 1000 & 300 & 500 \\
\hline 7 & Lord Buddha H.S.S. & 150 & 160 & 165 & 2 & 300 & 320 & 330 \\
\hline 8 & Star H.S.S. & 50 & 50 & 60 & 4 & 200 & 200 & 240 \\
\hline 9 & National Academy & 30 & 40 & 40 & 4 & 120 & 160 & 160 \\
\hline 10 & Holyland H.S.S. & 30 & 40 & 50 & 5 & 150 & 200 & 250 \\
\hline \multicolumn{6}{|c|}{ rand total } & 4020 & 4600 & 5304 \\
\hline
\end{tabular}

Frog consumption rate is increasing every year (Tab. 1) while the habitat loss, increase in uses of pesticides, encroachment of wetlands continue unabated resulting in decline in frog population. From interview it was learnt that in 2010, the collectors could collect100 frogs from within $200 \mathrm{~m}$ distance but in 2012 they got hardly 8-10 frogs in the same distance. It was also learnt that sometimes frog meat eaters collect thousands of frogs in one night using some new techniques.

As Tiger frog Hoplobatrachus tigerinus is an important element of ecosystem it has to be conserved. Though there is no any mention about the conservation of Tiger frog conservation in the biodiversity conservation law of Nepal but on the basis of anthropogenic impacts it is certain that if safeguard measures are not in practice, rehabilitization will be most expensive later on. To cut down the number of frogs to be dissected by a student in an academic year proper preservation of frog required. Two to three well preserved frogs are more than sufficient for a student to dissect out the frog to study all systems included in the syllabus. The second author has found (unpublished data) that the ratio of male is always higher. Thus collection of female frogs should be avoided as far as possible.

Authors would like to thank biology teachers of Higher Secondary Schols and +2 Colleges of Biratnagar for providing information. Thanks are also due to Sanjay Gurung and Amit Rawt for their help during field study.

\section{References}

Rai, K.R. 2005. Environmental impacts, systematic and distribution of herpetofauna from east Nepal. Ph.D. Thesis, Institute of Science and Technology, Tribhuvan University, Kathmandu, Nepal.

Schleich, H. \& W. Kaestle. 2002. Amphibians and Reptiles of Nepal. Koeltz Scientific Publication, Germany. pp. 175-279. 